\title{
Histopathology of skin and gills of fish in pulp mill effluents
}

\author{
E. Lindesjöö ${ }^{1}$, J. Thulin ${ }^{2}$ \\ ${ }^{1}$ Laboratory for Aquatic Ecotoxicology, Stockholm University, Studsvik, S-611 82 Nyköping, Sweden \\ ${ }^{2}$ Institute of Marine Research, Swedish National Board of Fisheries, PO Box 4, S-453 21 Lysekil, Sweden
}

\begin{abstract}
This study was one part of the Swedish multidisciplinary project Environment/Cellulose, which aimed to study biological consequences of discharges from pulp mills with chlorine bleaching. One year after the disappearance of very high prevalences of acute fin erosion of perch Perca fluviatilis in a Swedish pulp mill effluent, the skin of the caudal fin exhibited macroscopic thickening, indicating hyperplasia of the epithelium. In a study of the same species 3 mo after the disappearance of the acute fin erosion, gills with shortened filaments as well as fusion of secondary lamellae were found. However, a morphometric study of cellular and non-cellular structures of the secondary lamellae of the gill $1 \mathrm{yr}$ later could not demonstrate any differences between exposed and unexposed fish. A comparative study was made of goldfish Carassius auratus from a stream in New Zealand, used as a recipient for the effluent from a pulp mill producing pulp bleached with chlorine. Goldfish were found to have identical disease signs, acute and healed fin erosion, to those found in perch from the Swedish pulp mill effluent. Macroscopic thickening of the skin of the caudal fin was also found in the goldfish. The histopathology of the fins of these goldfish showing acute stages of fin erosion included edema and hyperemia in the dermis, plus associated necrosis of the distal part of the fins. This study concluded that the fin erosion described could be found in several fish species inhabiting different pulp mill effluents, with the most likely etiology being a physiological disturbance induced by one or more of the many toxicants present in the effluents
\end{abstract}

KEY WORDS: Pollution Fin erosion $\cdot$ Pulp mills $\cdot$ Perch $\cdot$ Goldfish

\section{INTRODUCTION}

In the study of anthropogenic effects on the aquatic environment, morphologic responses of fish can be used as indicators for toxicants. The skin and gills, being in direct contact. with the surrounding environment, and the liver, the major target organ for xenobiotics, are of special interest for such studies (Dethlefsen et al. 1984, Hinton et al. 1987). Consequently, several studies of the gross pathology of fish from polluted environments have suggested that increased prevalences of skin lesions, such as fin erosion and fin rot, are related to pollution (Mearns \& Sherwood 1974, Murchelano 1975, Ziskowski \& Murchelano 1975, McDermott-Ehrlich et al. 1977). In studies of Dover sole Microstomus pacificus from the California Bight, Sherwood \& Mearns (1977) and Cross (1984) presented strong indications that fin lesions were caused by a polluted aquatic environment.
In a recent study of fish diseases in a pulp mill effluent area, very high frequencies of fin erosion of perch Perca fluviatilis and ruffe Gymnocephalus cernua could be correlated to the discharge from the mill (Lindesjöö \& Thulin 1990). Several experimental studies have also been performed in which fish were exposed to a large variety of substances and to acid water, with the purpose of studying histopathological changes of the skin and the gill. Examples are chromate (Temmink et al. 1983), crude petroleum (Burton et al. 1984), nitrofurazone (Wise et al. 1987), mercury (Pereira 1988) and acid water (Daye \& Garside 1976, Zuchelkowski et al. 1986). However, very few field studies of skin and gills have used quantitative morphologic methods for monitoring aquatic pollutants.

This study follows previous reports on the outbreak of fin erosion of perch and ruffe (Thulin et al. 1988, Lindesjöö \& Thulin 1990) and aims to quantify cellular 
$\mathrm{Cl}$

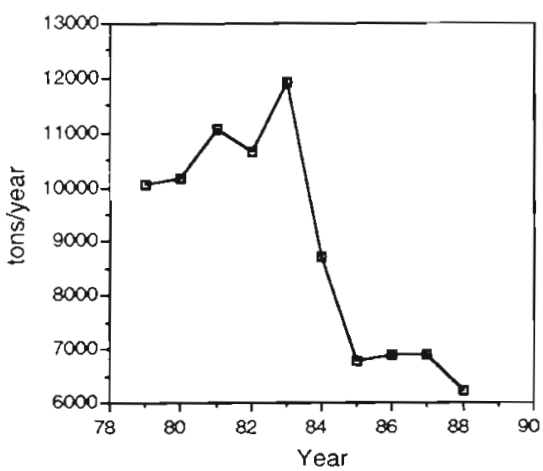

COD

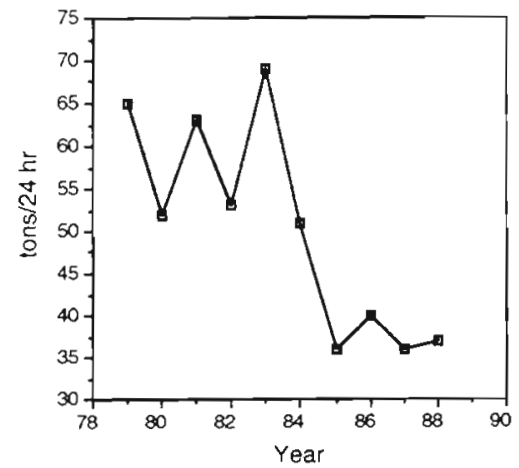

Suspended solids

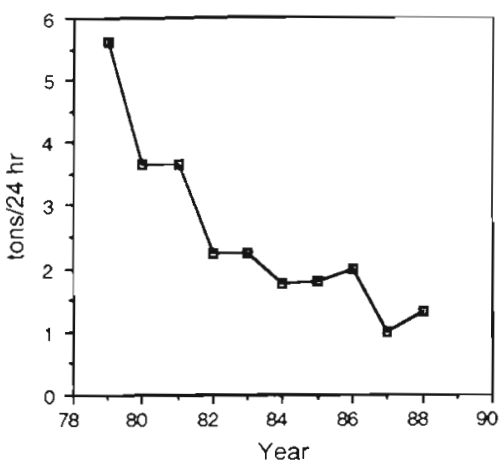

Fig. 1. Effluent characteristics and production data from Norrsundet pulp mill during 1979-88. Cl: elemental chlorine used in bleaching; COD: chemical oxygen demand. Data supplied by Norrsundet Bruk AB

and subcellular changes in the skin and gills of fish from pulp mill effluents, using morphological methods. The normal cellular structure of the skin of perch, including temporal variation and sexual dimorphism, has been investigated earlier with both light and electron microscopy (Lindesjöö 1992).

\section{MATERIALS AND METHODS}

Investigation areas. The main part of the study took place in 1984 and 1985 at the Norrsundet pulp mill situated on the east coast of Sweden. The mill produces bleached chemical pulp and at the time of sampling produced $230000 \mathrm{t}$ bleached pulp per year with the following bleaching sequences: bleaching started with oxygen delignification then pulp was distributed to 2 bleaching lines with the sequences $\mathrm{O}\left(\mathrm{C}_{85}+\mathrm{D}_{15}\right)(\mathrm{EO}) \mathrm{D}$ and $\mathrm{O}\left(\mathrm{C}_{85}+\mathrm{D}_{15}\right)$ (EO)DED, where $\mathrm{C}=$ chlorine, $\mathrm{D}=$ chlorine dioxide, $\mathrm{E}=$ sodium hydroxide and $\mathrm{O}=$ oxygen. The mill was partly rebuilt in 1982-1983, with reconstruction and technical improvements of the processing technique, resulting in a lower environmental load of effluent after 1984 (Fig. 1).

The pulp mill is situated in the brackish Gulf of Bothnia, Sweden. The salinity in the area is stable $(5 \%)$ and there are no major freshwater inputs or other local pollution sources. The topography of the effluent area allowed a series of stations to be chosen at increasing distances from the pulp mill, but all having similar characteristics in terms of depth, exposure and temperature regime (Fig. 2). The concentration of effluent decreased with increasing distance north of the pulp mill (Kolset \& Heiberg 1988). This clear gradient could be expressed in terms of the content of extractable organic chlorine in the muscle of perch (Fig. 3).

Perch were sampled at Stns 2, 4 \& 6 in the effluent area and also at the reference area Forsmark (Fig. 2). The study was conducted within 1 yr after the disap- pearance of a very high prevalence of acute fin erosion of perch and ruffe found in the Norrsundet effluent area in May 1984 (Lindesjöö \& Thulin 1990).

The Kinleith pulp mill, New Zealand, produces bleached chemical pulp. At the time of sampling, November 1988, the raw materials used for production were $95 \%$ softwood (Pinus radiata), and $5 \%$ hardwood (Bielschmedia tawa). The following 2 bleaching se-

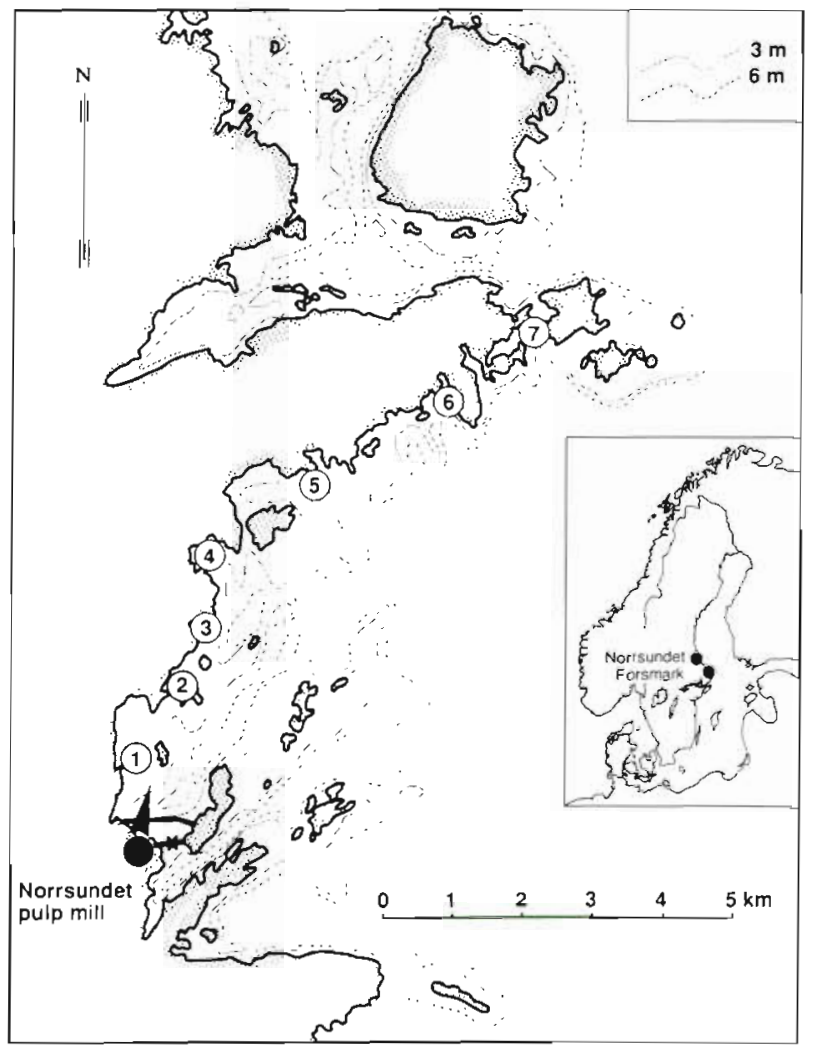

Fig. 2. Norrsundet pulp mill effluent area, Sweden, showing the discharge point at Norrsundet (arrow), sampling stations (Stns 2, 4 \& 6 used in this study) and the reference area (Forsmark) 


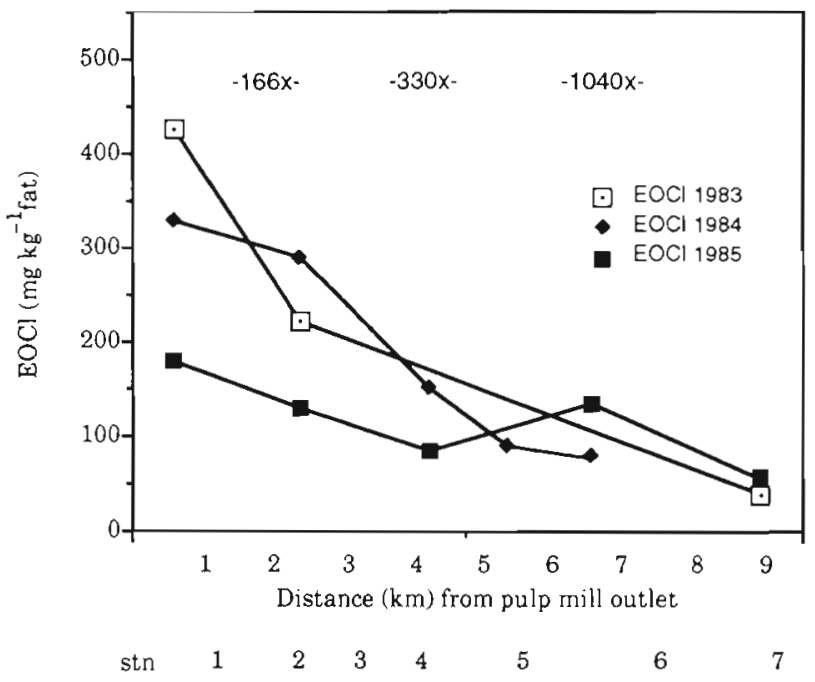

Fig. 3. Perca fluviatilis. EOCl (extractable organic chlorine) in muscle of perch from the Norrsundet effluent area, and calculated dilution ( $166 \times$ etc.) of effluent. Data modified from Södergren (1989)

quences were used at the Kinleith mill: C-E-D-H-P and $\mathrm{D}_{30} / \mathrm{C}_{70}-\mathrm{E}_{0}-\mathrm{D}-\mathrm{E}-\mathrm{D}$, where $\mathrm{D}=$ chlorine dioxide, $\mathrm{C}=$ chlorine, $\mathrm{E}=$ sodium hydroxide, $\mathrm{H}=$ sodium hypochlorite, $\mathrm{P}=$ hydrogen peroxide. Pulp production was $285000 \mathrm{t}$ unbleached pulp and $130000 \mathrm{t}$ bleached pulp $\mathrm{yr}^{-1}$ (data supplied by New Zealand Forest Products). The mill had primary and secondary external treatment. The processed water, totalling $280 \mathrm{mil}-$ lion $\mathrm{l} \mathrm{d}^{-1}$ with a loading of $3 \mathrm{t} \mathrm{d}^{-1}$ of $\mathrm{BOD}$ (biological oxygen demand), was released into Kopakorahi Stream which has its outflow in Lake Maraetai. After July 1991 the process at the Kinleith mill was changed to include a new bleaching sequence: $\mathrm{O}-\mathrm{D}-\mathrm{E}_{0}-\mathrm{D}$.

The most abundant fish species in the stream were goldfish Carassius auratus and rudd Scardinius erythropthalmus. In the lake, brown trout Salmo trutta, rainbow trout Oncorhymchus mykiss and common bully Gobiomorphus cotidianus were also found. Goldfish were sampled at 3 different stations (Fig. 4). The first station was situated in Kopakorahi Stream which had high concentrations of effluent. At an intermediate station in Lake Maraetai, pulp mill effluents were only

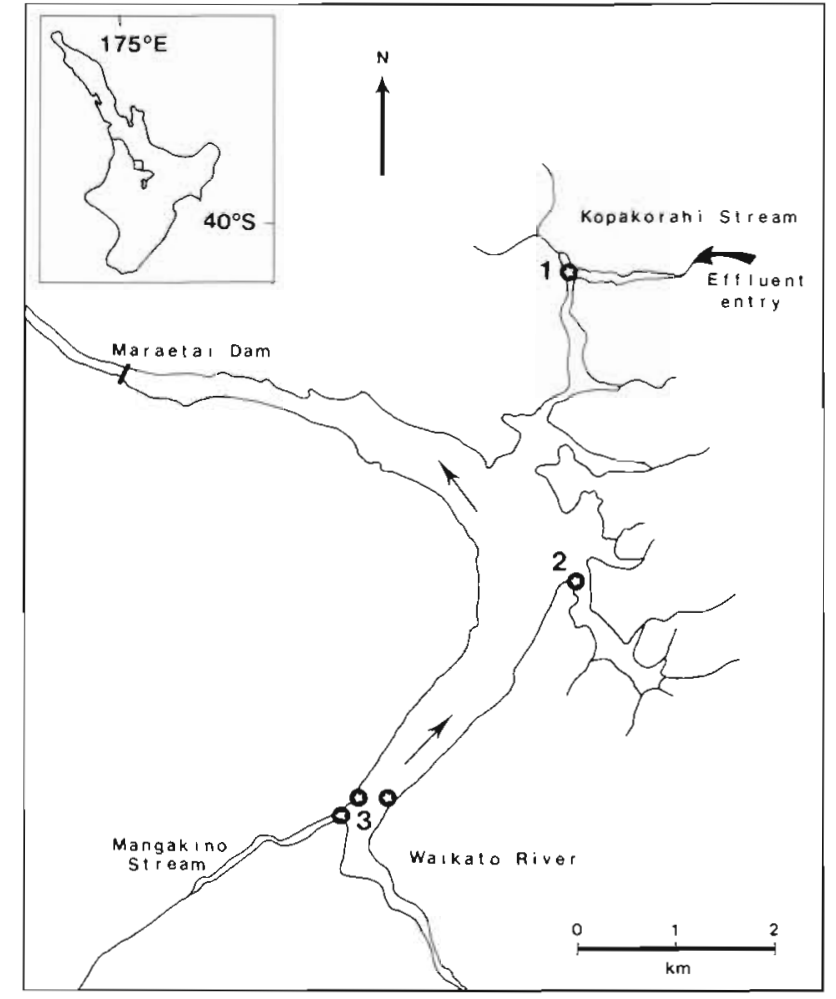

Fig. 4. Kinleith pulp mill effluent area, North Island, New Zealand, showing the effluent entry and the location of the 3 sampling stations

temporarily affecting the area. The influence of the pulp mill effluent at this station was strongly affected by water regulation downstream at Maraetai Dam. The third station, situated approximately $3 \mathrm{~km}$ upstream in the lake, was not affected by the effluent at any time.

Sampling. Skin: In June 1985, sexually mature perch were sampled for skin analysis at Stns 2, $4 \& 6$ in the Norrsundet pulp mill area and also at Forsmark (Table 1). The perch at Norrsundet were in the spawning phase while those from the reference area had just finished spawning. The perch were caught with gill nets, which were emptied each morning following deployment the previous day. The perch were immediately cut from the net with scissors, without coming into contact with the boat deck, and then placed in a

Table 1. Perca fluviatilis. Epidermal thickness (corrected for sex; see text), epithelial cell size, and length and sex of perch from Norrsundet effluent area (Stns $2,4 \& 6$ ) and Forsmark (reference area)

\begin{tabular}{|c|c|c|c|c|c|c|c|c|c|c|c|}
\hline \multirow[t]{2}{*}{ Station } & \multicolumn{3}{|c|}{ Epidermal thickness $(\mu \mathrm{m})$} & \multicolumn{3}{|c|}{ Epithelial cell size $\left(\times 10^{-11} \mathrm{~m}^{2}\right)$} & \multicolumn{3}{|c|}{ No. of epithelial cell layers } & \multirow{2}{*}{$\begin{array}{l}\text { Mean length } \\
(\mathrm{mm} \pm \mathrm{SE})\end{array}$} & \multirow[t]{2}{*}{$\mathrm{n}\left(\sigma^{\pi} / \rho\right)$} \\
\hline & Mean \pm SE & Min & Max & Mean \pm SE & Min & $\operatorname{Max}$ & Mean \pm SE & Min & $\operatorname{Max}$ & & \\
\hline Reference & $114 \pm 10.8$ & 55 & 157 & $3.05 \pm 0.343$ & 1.75 & 4.90 & $10.9 \pm 0.62$ & 7.5 & 13.5 & $223 \pm 12.7$ & $10(4 / 6)$ \\
\hline 2 & $161 \pm 24.4$ & 64 & 352 & $4.75 \pm 0.484$ & $3: 24$ & $8: 35$ & $12.1 \pm 0.90$ & 8.0 & 17.0 & $220 \pm 7.5$ & $11(10 / 1)$ \\
\hline 4 & $140 \pm 13.2$ & 96 & 204 & $4.23 \pm 0.226$ & $3: 47$ & 5.75 & $11.7 \pm 0.79$ & 8.5 & 17.0 & $238 \pm 6.8$ & $10(2 / 8)$ \\
\hline 6 & $123 \pm 13.5$ & 79 & 213 & $4.92 \pm 0.243$ & $3: 59$ & $6: 17$ & $11.9 \pm 1.21$ & 9.5 & 22.5 & $240 \pm 5.0$ & $10(5 / 5)$ \\
\hline
\end{tabular}


tank containing water. This careful handling was necessary to avoid any mechanical injury to the epidermis Dead perch were discarded and live ones transported to the laboratory. Only the caudal fin was chosen for sampling because the skin on this fin was previously found to be more sensitive to pollution than skin on other parts of the body (Lindesjö \& Thulin 1990).

The goldfish in the New Zealand studies were caught both with gill nets and with fykes and sampling was carried out in the same way as for perch. A total of 170 goldfish of both sexes, ranging in length between 90 and $245 \mathrm{~mm}$, were sampled for pathological analysis.

Gills: In August 1984, gills of female perch, ranging in length between 215 and $245 \mathrm{~mm}$, were sampled for histopathological analysis at Stns $2,4 \& 6$ in the Norrsundet pulp mill area and in Forsmark. A total of 10 perch were analysed from each station. The fish were caught using the method described above.

in addition, the individual perch caught in June 1985 at Norrsundet and Forsmark were also used for gill sampling.

Fixation, embedding and sectioning. Skin: The upper part (Fig. 5, A) of the caudal fin was dissected and fixed in a solution of $3 \%$ glutaraldehyde in $0.1 \mathrm{M}$ phosphate buffer, pH 7.4. Fixation for TEM was made with the purpose of investigating whether subcellular changes of the skin epithelium of perch occurred as a result of exposure to pulp mill effluents. After fixation, $3 \times 10 \mathrm{~mm}$ strips were cut from a defined area $(\mathrm{B})$ of each fin. A modification of a rapid embedding technique (A. McVicar unpubl.) for TEM was used with the following steps: 2 rinses in buffer $(2 \times 5 \mathrm{~min})$; postfixation in $1 \% \mathrm{OsO}_{4}(1 \mathrm{~h})_{i} 2$ rinses in buffer $(2 \times 5 \mathrm{~min})$; rinse in $30 \%$ acetone; dehydration in a graded series of acetone, 30, 50 and $70 \%(2 \times 5$ min at each concentration), and finally in $100 \%$ acetone $(3 \times 5 \mathrm{~min})$. There then followed infiltration of samples in a mixture (1/1) of $100 \%$ acetone and Agar 100 epoxy resin (30 min),

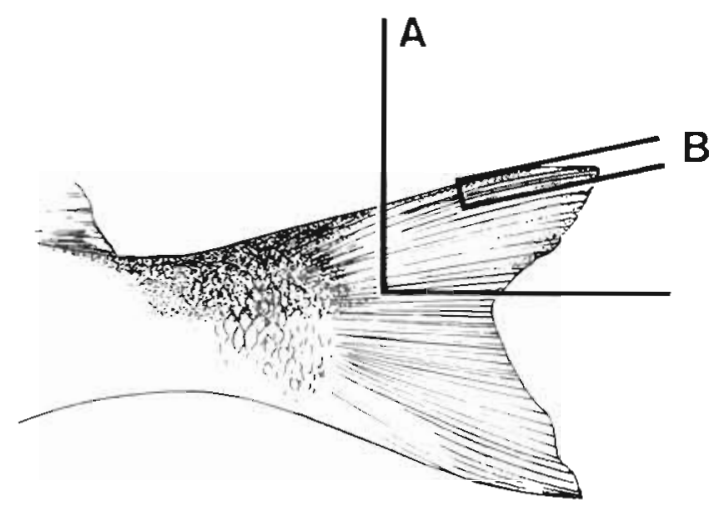

Fig. 5. Perca fluviatilis. Part of caudal fin of perch sampled in the field (A) and part dissected in the laboratory for microscopic analysis (B) infiltration in pure Agar 100 ( $2 \times 10 \mathrm{~min})$, embedding in Agar 100 , and polymerizing at $60^{\circ} \mathrm{C}$ overnight. Cross sections, $2 \mu \mathrm{m}$ thick, were cut below the distal end of the fin, where the fin ray is well developed (Haas 1962). The sectioning area had to be accurately defined because of the need to measure dermal thickness, which increased with decreasing distance from the base of the fin. Epidermal thickness did not show a similar correlation, however. Transverse sections of the goldfish material were also made. The sections were stained with methylene blue and mounted. In addition, thin sections for TEM were taken from each block, mounted on copper grids, then stained with $4 \%$ uranyl acetate for $20 \mathrm{~min}$ followed by lead citrate for $5 \mathrm{~min}$ according to Reynolds (1963). Skin samples were also prepared for SEM with the following steps: dehydration in graded concentrations of ethanol up to absolute ethanol, stepwise replacement of ethanol by Freon TF and critical point drying, using liquid $\mathrm{CO}_{2}$. The specimens were mounted on stubs and coated with goldpalladium in a sputter coater.

Gills sampled in August 1984: The central part of the second gill arch on the left side was dissected and fixed in $3 \%$ glutaraldehyde in $0.1 \mathrm{M}$ P-buffer, $\mathrm{pH} 7.4$. These tissues were dehydrated in a graded series of ethanol concentrations up to absolute ethanol, infiltrated in xylol and embedded in paraffin wax. The blocks were cut into $5 \mu \mathrm{m}$ sections and stained with haematoxylin and eosin. Gills were also prepared for SEM with the following steps: dehydration in graded concentrations of ethanol up to absolute ethanol, stepwise replacement of ethanol by Freon TF and critical point drying, using liquid $\mathrm{CO}_{2}$. The specimens were mounted on stubs and coated with gold-palladium in a sputter coater.

Gills sampled in June 1985: The central part of the second gill arch on the left side was sealed with 2 artery forceps to avoid a quick drop in blood pressure, dissected, and pre-fixed in a solution of $3 \%$ glutaraldehyde in $0.1 \mathrm{M}$ P-buffer, pH 7.4. After pre-fixation the forceps were removed and the gill was placed in a fresh solution of $3 \%$ glutaraldehyde. The central part of the fixed gill was cut out, post-fixed in phosphate-buffered $1 \% \mathrm{OsO}_{4}$. dehydrated in a series of ethanol concentrations, passed through propylene oxide and embedded in Epon. The blocks were sectioned at $1 \mathrm{~mm}$ and stained with methylene blue. Sections for TEM were also prepared using the same processing method as for the skin.

Diagnostic methods. Skin: Pathological changes of the skin of the fin were examined with both stereo- and light microscopy. The number of cell layers in the $2 \mu \mathrm{m}$ sections were counted using light microscopy, and expressed as means of the maximum and minimum number of layers. An analysis of epidermal and dermal thickness was made using photomicrographs of the $2 \mu \mathrm{m}$ sections. The sections were photographed with 
the light microscope and then copied with a final enlargement of $208 \times$ onto a $18 \times 24 \mathrm{~cm}$ sheet of paper. To eliminate observer bias, each sheet was assigned an arbitrary code, and the sheets were mixed before analysis. The area of the epidermis and dermis, bounded by 2 lines $11 \mathrm{~cm}$ apart and perpendicular to the skin surface, was measured using a lattice with 88 points per $\mathrm{dm}^{2}$. The thickness of the epidermis and of the dermis were expressed as the average height of the cross-sectional area of each.

The ultrastructural analyses were made on photomicrographs of TEM sections from 2 areas of the outer layer of each epidermis. A magnification of $1000 \times$ was used and the photomicrographs were copied, with a final enlargement of $6660 \times$, onto a $17.5 \times 19 \mathrm{~cm}$ sheet of paper. The average crosssectional area of the cytoplasm and nuclei of the epithelial cells, and the amount of intercellular space, were measured using the same lattice as described above. The relative areas of nucleus and cell ( $=$ nucleus + cytoplasm) were then expressed as a ratio (the nucleus-to-cell index).

Gills: Gills sampled in August 1984 were examined for pathological changes with both stereo- and light microscopy

Gills sampled in June 1985 were examined for pathological changes with the aid of a stereomicroscope. The morphometric analysis used in this study was adapted from the method developed by Hughes \& Perry (1976). A 100 point Mertz grid was superimposed on magnified micrographs of the $1 \mathrm{~mm}$ thick Epon sections of the gills. Each micrograph covered 4 to 6 secondary lamellae and 2 different fields of view were analysed for each individual. The following cellular and non-cellular structures of the secondary lamellae were analysed:

- Water space between secondary lamellae.

- Tissue-occupied regions outside the basement membrane

- Non-tissue spaces outside the basement membrane,

- Pillar cells including the basement membrane, ery-

throcytes, and

- Blood plasma and leucocytes.

Calculations were made of secondary lamellar volume in the lamellar region; total volume of the epithelia outside the basement membrane and tissue volume outside the basement membrane.

\section{RESULTS}

\section{Skin of perch}

\section{General pathology}

The majority of fish from Stn 2 were observed (by stereomicroscopy) to have a very pronounced greyish opaque appearance to the skin surface. These specimens were also recorded as having a thickening of the skin (Figs. 6 to 9). Four individuals from Stn 2
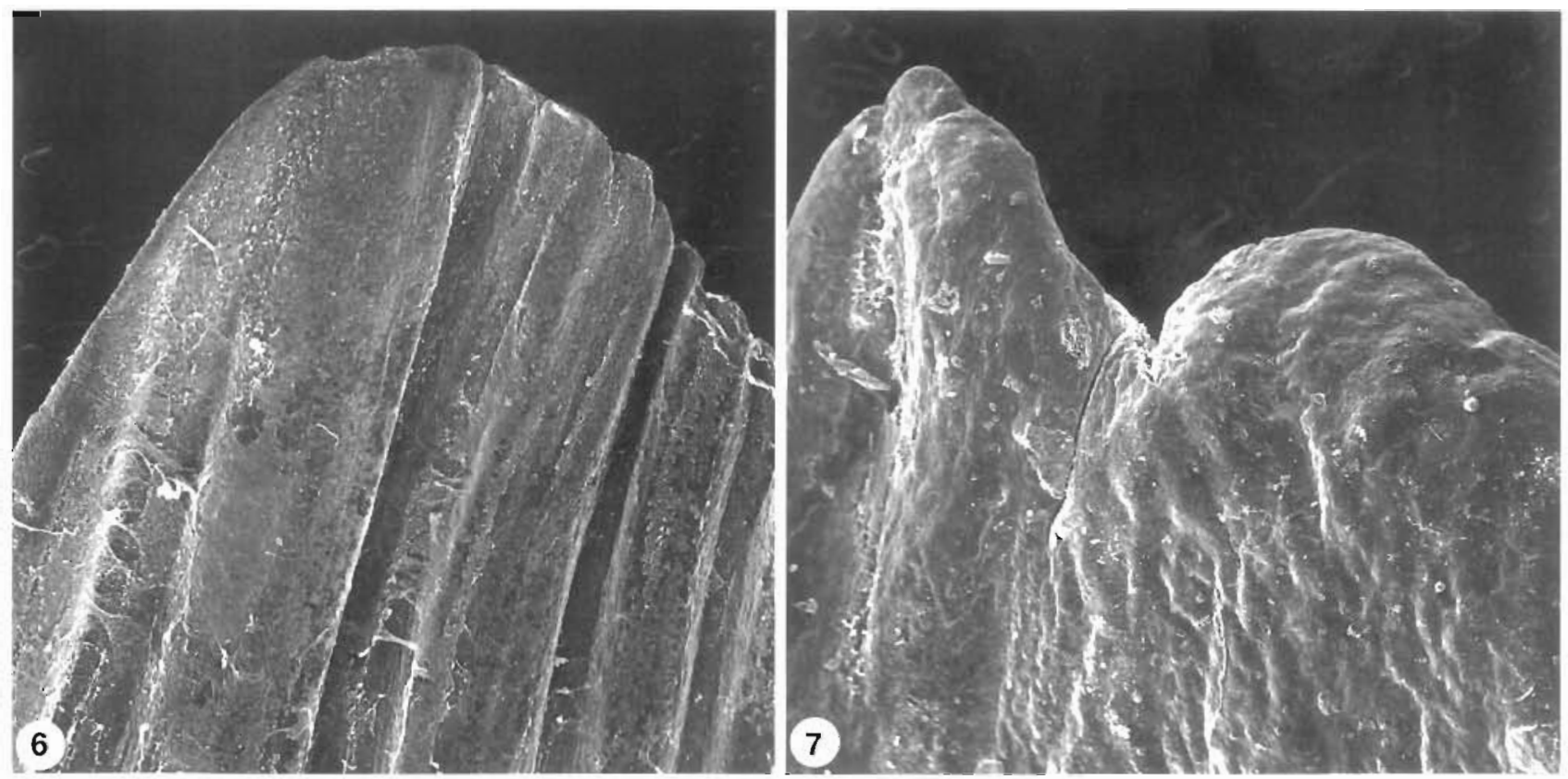

Figs. $6 \& 7$. Perca fluviatilis. Caudal fin of perch $\times 29$. Fig. 6. Fin with normal skin epithelium from reference area. Fig. 7. Fin with thickened epidermis from Stn 2 at Norrsundet pulp mill 

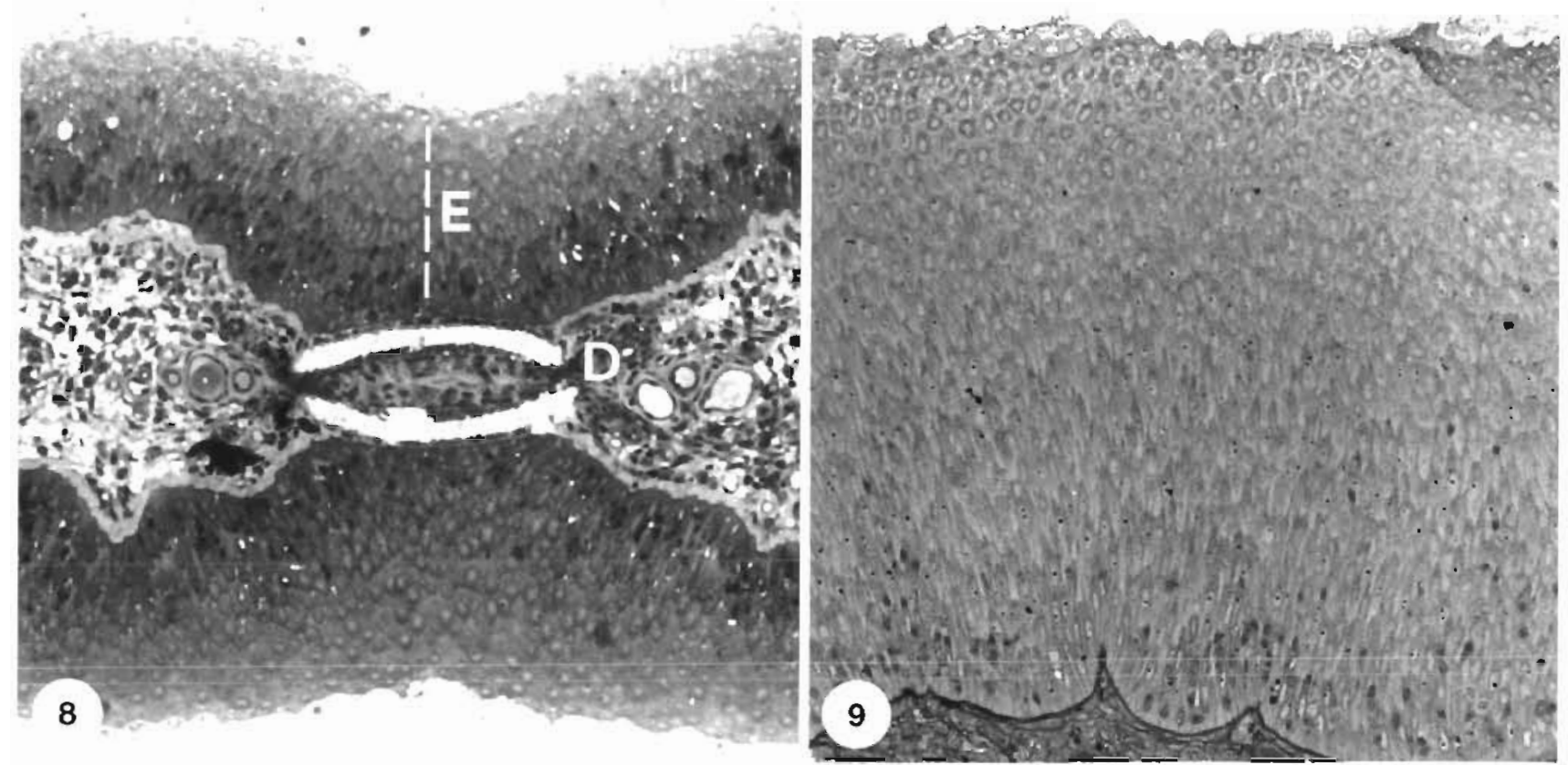

Figs. 8 \& 9. Perca fluviatilis. Transverse section of caudal fins of perch $\times 214$. Fig. 8 . Fin with normal epidermal thickness from reference area. Fig. 9. Fin with thickened epidermis from $\overline{\operatorname{Stn} 2}$ at Norrsundet pulp mill

and 5 from Stn 4 were also recorded in the field as showing typical signs of healed fin erosion, as previously described by Lindesjöö \& Thulin (1990). At Stn 6, a single individual showed increased infiltration of leucocytes in the epithelium. These cells were identified as granulocytes and macrophages (Figs. 10 to 12 ). This particular fish had no signs of external disease such as ulceration or fin erosion. No other perch were found to have any pathological changes of the epidermis or of the dermis. Furthermore, no bacteria could be found, by light or electron microscopy, in the tissues of fish from any of the stations

\section{Epidermal thickness}

In a previous study, sexual dimorphism of the skin of perch was demonstrated (Lindesjöö 1992). Because of differing sex ratios at the different stations in this study, a correction factor for sex was applied. The correction factor was based on sampling in the reference area in June 1987, showing mean epidermal thicknesses of 102.2 and $126.5 \mu \mathrm{m}$ in females and males respectively. Thus the epidermal thick- ness of females from all stations in this study were corrected by multiplication by a factor of 1.238 .

Perch at Stn 2 were found to have the largest mean epidermal thickness (Fig. 13). The epidermal thickness at this station was $161 \mu \mathrm{m}$. At Stns $4 \& 6$ and the

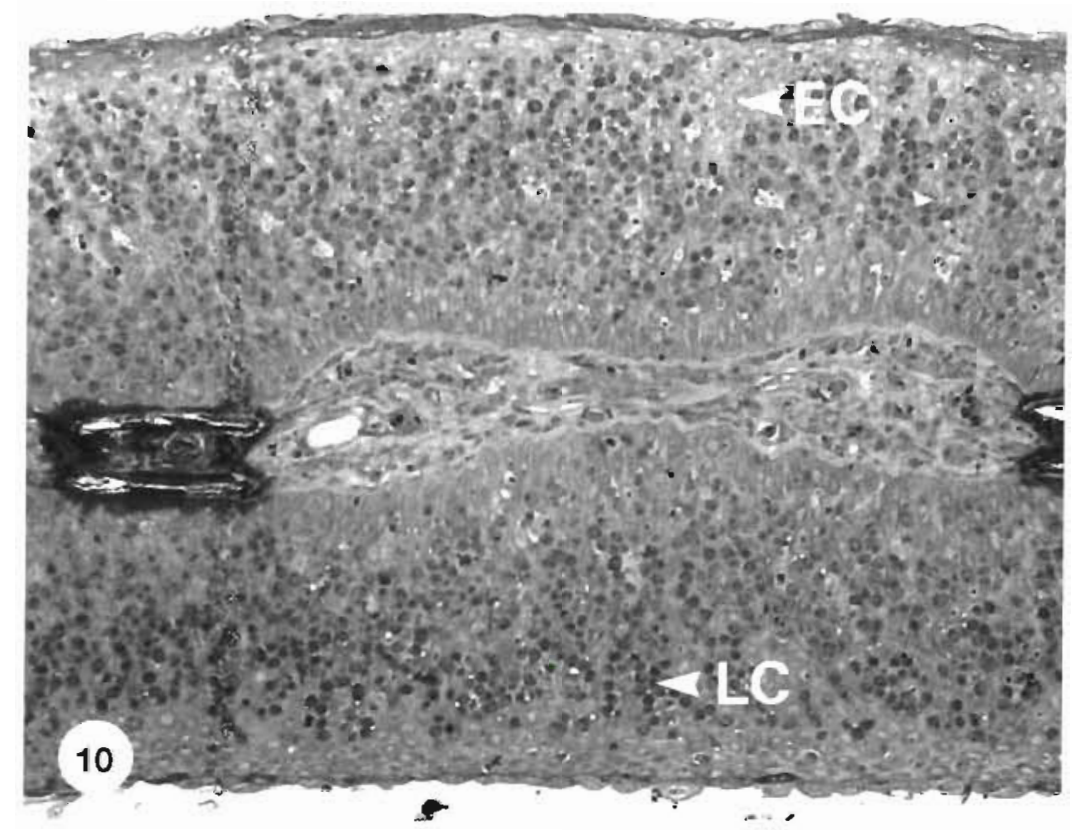

Fig. 10. Perca fluviatilis. Transverse section of caudal fin of perch with a marked infiltration of leucocytes in the epidermis from Stn 6 at Norrsundet pulp mill; $\times 200$ 


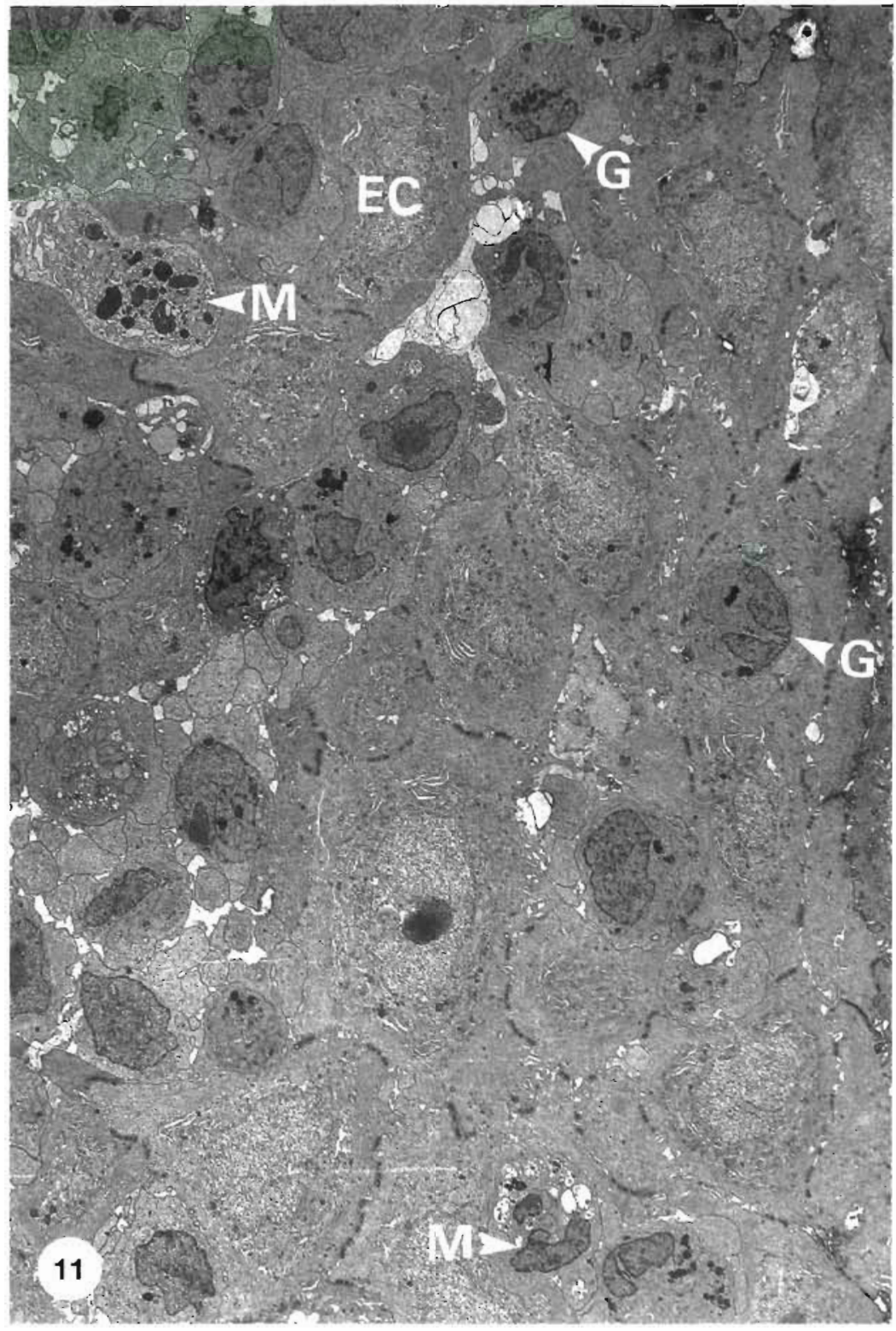

Fig. 11. Perca fluviatilis. Outer layer of the epidermis of the individual shown in Fig. 10. Outermost layer orientated to the right; $\times 2460$. EC: epithelial cell; G: granulocyte; M: macrophage

reference area, the thicknesses were 140,123 and $114 \mu \mathrm{m}$ respectively. The difference between $\operatorname{Stn} 2$ and the reference area was not statistically significant ( $p=0.078$, Mann-Whitney $U$-test). However, the highest value for epidermal thickness (352 $\mu \mathrm{m}$ ) recorded at Stn 2, was clearly the result of hyperplasia (Figs. $7 \& 9$ ).

The mean numbers of epithelial cell layers in fish from different stations did not show any statistically significant differences (Table 1).

To evaluate a possible relationship between healed fin erosion and increased epidermal thickness, the 9 individuals from the Norrsundet area found to have healed fin erosion were compared with the 22 individuals with unaffected fins from the same area. Those with regenerated fins were found to have a mean epidermal thickness of $164 \mu \mathrm{m}$, compared with a mean thickness of $133 \mu \mathrm{m}$ in those with unaffected fins. However, the difference was not statistically significant $(p=0.361$, Mann-Whitney $U$ test).

\section{Epithelial cell size}

No sexual dimorphism of the epithelial cell size of perch from Norrsundet was found in this study or in the one performed in June 1987 (Lindesjöö 1992). Thus, results from both sexes were pooled in the present study.

At the reference station and at Stns $2,4 \& 6$, the mean epithelial cell sizes were $3.05,4.76,4.23$ and $4.92 \times$ $10^{-11} \mathrm{~m}^{2}$ respectively (Fig. 14). The epithelial cells of perch from all stations in the Norrsundet area were significantly larger than those from. the reference area $(p<0.018$, MannWhitney $U$-test)

\section{Nucleus to cell index}

No differences between the different stations in the nucleus-to-cell index were found. The mean ratios were 0.117 (reference), 0.118 (Stn 2), 0.113 (Stn 4) and 0.111 (Stn 6).

\section{Gills of perch}

\section{General pathology}

Two of the perch from Stn 2, caught in August 1984, were found to have pathological changes of the gills. One of them had shortening of all filaments with fusion of secondary lamellae at the tip of the filaments. Some of the filaments were also ramified. The other had bent distal parts of the filaments (Fig. 15). Some filaments were also shortened, with fusion of secondary lamellae. Both these perch had fins with healed fin erosions. Some specimens were found to have large 


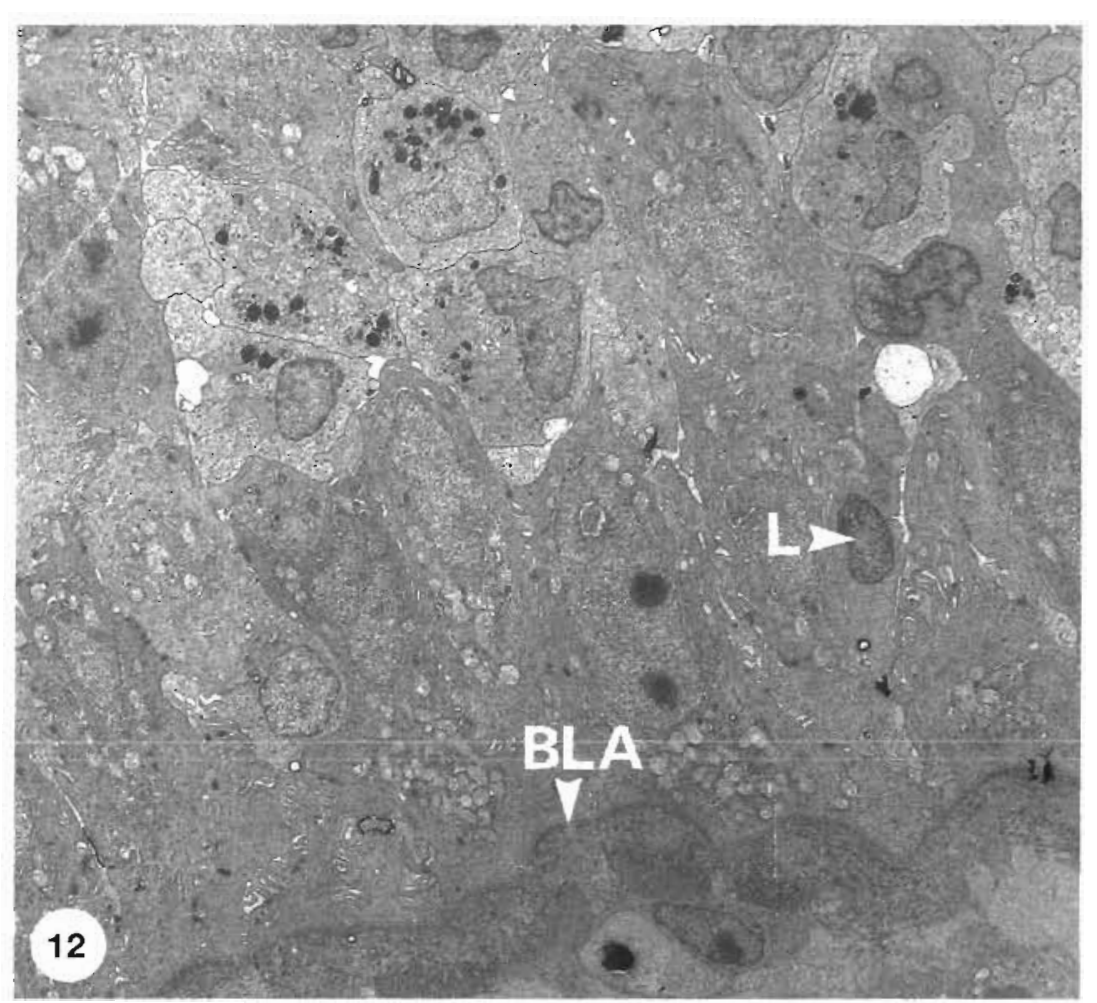

Fig. 12. Perca fluviatilis Basal layer of the epidermıs of the individual shown in Fig $10 ; \times 2460$ BLA basement membrane; L lymphocyte

\section{Gill morphometry}

The morphometric analysis of the secondary lamellae did not show any significant differences between perch from different stations. No deviation of the cellular component or increase of the diffusion distance were found.

\section{Skin of goldfish}

At the river station in New Zealand, the fins of goldfish were found to have disease signs identical with those previously found in the Norrsundet effluent area, namely acute fin erosion with 'bleeding fins', and healed fin erosion (Lindesjöö \& Thulin 1990). Healed fin erosion was also found in samples at the intermediate station, whereas at the lake station, unaffected by any effluents, fun erosion was not identified. A consistent finding by stereomicroscopy in the majority of fins from goldfish caught at the river station was a thickened skin with a greyish

deposits of mucus on the surface of the gill epithelium. However, the secretion of mucus varied greatly at all stations, including the reference station. No other pathological changes were found in the gills of fish at any of the stations, including the reference station. No pathological changes were found in the gills sampled in June 1985.

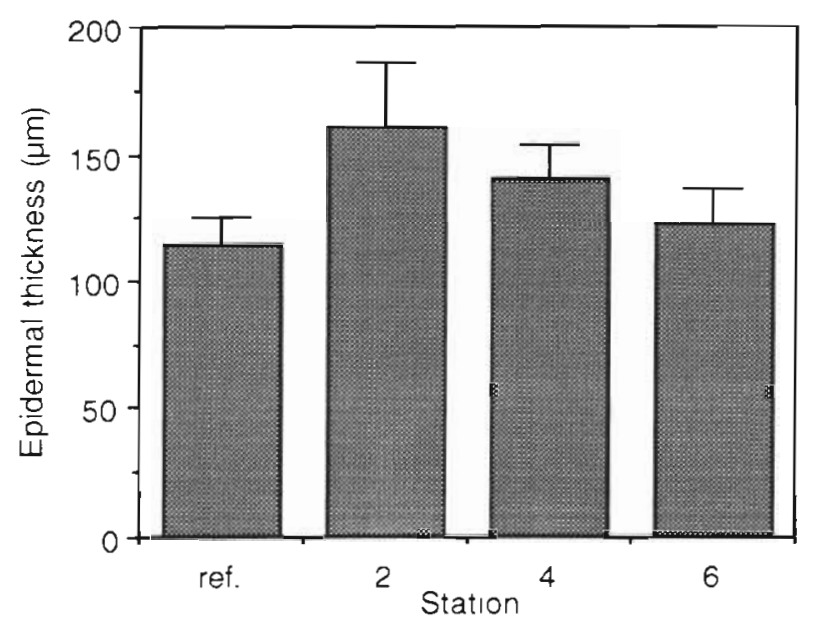

Fig 13. Perca fluvatilss Mean epidermal thickness ( \pm SE) of caudal fin of perch from Norrsundet pulp mill effluent area and reference area opaque surface, an appearance identical to that of perch funs from Stn 2 in Norrsundet. Sections of fins with acute fin erosion exhibited edema, necrosis and hyperemia in the dermis. These pathological changes were restructed to the distal part of the fin (Figs. 16 to 18 ). No cellular changes could be found in the part of the epithelıum covering unaffected dermis. However,

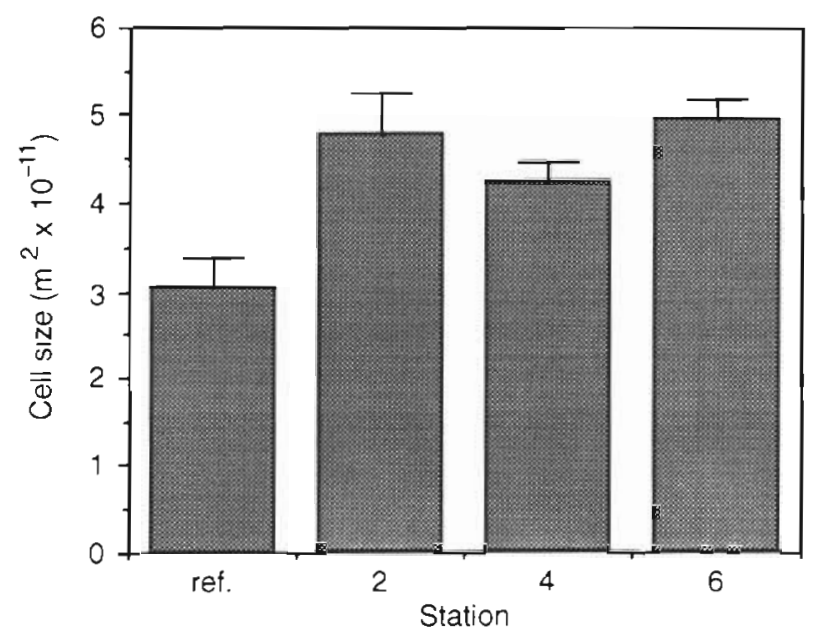

Fig. 14 Perca fluviatilis. Epithelial cell size ( \pm SE) of caudal fin of perch from Norrsundet pulp mill effluent area and reference area 


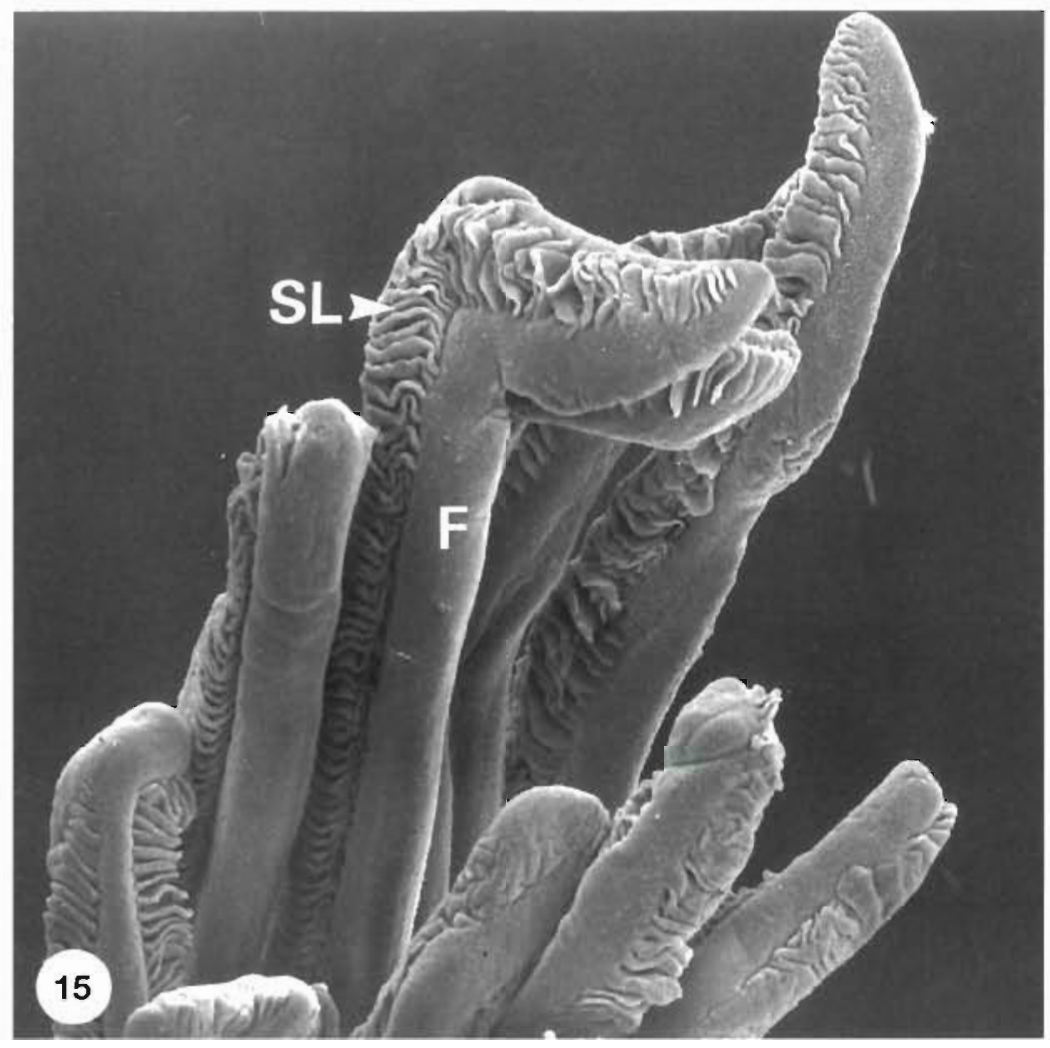

Fig. 15. Perca fluviatilis. Gill filaments of perch from Stn 2 at Norrsundet pulp mill with bent and/or shortened filaments and fusion of secondary lamellae; $\times 40$. F: gill filament; SL: secondary lamellae

similar histopathological pattern is known from the disease lepidorthosis (Hibiya 1982) described as accumulations of exudate in the dermis, splitting up of connective tissue of the dermis, and rupture of capillaries leading to hemorrhaging. Hypertrophy of the epidermis was also observed. Several causative factors were suggested for the disease, including toxic substances. Unfortunately the disease was not illustrated with a photomicrograph and little information on lepidorthosis is available.

The histological sections in our studies did not reveal any evidence of bacteriological agents. Similar findings were made in other areas where increased prevalences of fin erosion was found in contaminated areas and where this did not appear to be the result of an infectious process (Klontz \& Bendele 1973, Murchelano 1975. Wingert et al. 1976).

During sampling of the goldfish, both acute and healed stages of the disease were found, while in the case of perch the acute stages had disappeared 1 yr earlier. However, a macroscopic thickening of the epithelium was found in both fish species at the

in the distal part of fins with a damaged dermis, the basement membrane was disrupted, with an associated necrosis of the epithelial cells (Figs. 19 \& 20). No bacteria could be detected in the light and electron microscopy sections, and no inflammatory response was found.

\section{DISCUSSION}

The study clearly showed that goldfish in the New Zealand pulp mill effluent suffered from a fin disease with signs identical to those previously reported from perch with fin erosion in a Swedish pulp mill effluent (Lindesjöö \& Thulin 1990). Sindermann (1984) proposed 'actions of chemical stressors on mucus and/or epithelium' as being one possible cause of fin erosion. The expected pathological change in relation to this disease would be a primary necrosis of cells in the epidermis. However, the histopathological study of acute fin erosion of goldfish from the pulp mill effluent clearly indicated that the erosion originated from a physiological disorder causing hyperemia of the dermis. This in turn led to necrosis of the fin epithelium. A stations most subjected to effluent. Increased epidermal thickness has previously been associated with fin erosion. In studies of fin erosion of flatfish living in polluted environments, epidermal hyperplasia of the fins was one of the most consistent histological findings (Wellings et al. 1976, Murchelano \& Ziskowski 1982). However, despite the largest mean epidermal thickness being found in perch at the most polluted station in the present study, the difference could not be statistically confirmed ( $p=0.078$ ) by the morphometric study. The maximum recorded thickness in the effluent area was $352 \mu \mathrm{m}$, at the station where very high prevalences of acute fin erosion were found the previous year (Lindesjöö \& Thulin 1990), whereas in a morphological study of the skin of perch (Lindesjöo 1992) the maximum individual epidermal thickness was never found to exceed $194 \mu \mathrm{m}$. The individual having this greatly thickened epithelium had epithelial cells of normal size, i.e. the increased growth of the epithelium was the result of hyperplasia.

In the previous morphological study of perch epithelium (Lindesjöö 1992), sexual dimorphism was demonstrated. This shows clearly that if changes of epidermal thickness of fish are to be studied in relation to envi- 

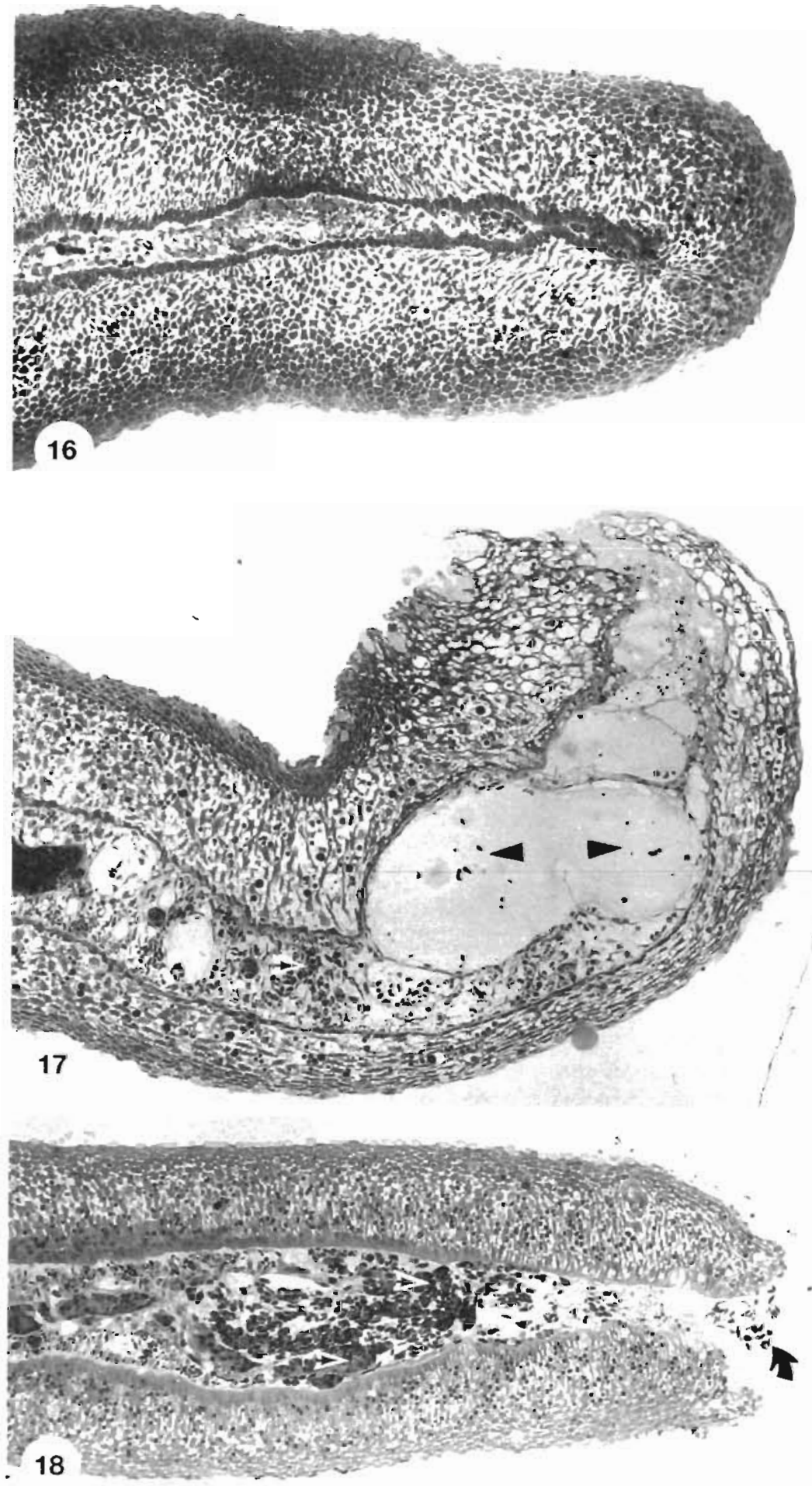

Figs. 16 to 19. Carassius auratus. Longitudinal sections of caudal fins of goldfish, $\times 124$. Fin with normal epidermis and dermis. Fig. 1.6. Fin with normal epidermis and dermis. Fig. 17. Fin from a pulp mill effluent area in Kopakorahi Stream, New Zealand, with acute erosion showing hyperemia (white/black arrows) and edema (black arrows) of the dermis, and necrosis (black arows) of the epidermis. Fig. 18. Fin from a pulp mill effluent area in Kopakorahi Stream, New Zealand, with acute fin erosion showing hyperemia (white/black arrows) and release of blood cells (black arrow) ronmental effects, sex must be taken into consideration. When sampling was conducted in the Swedish effluent, pathological deviations other than hyperplastic growth of the epidermis were expected, such as necrosis of the cells in the epithelium. Sexual differences related to these changes were not expected, and consequently the different sex ratios at the different sampling stations were not taken into consideration. In addition, it was not possible to repeat the study due to the improvement of the effluent, which had resulted in the disappearance of acute fin erosion. However, the existence of a relationship between increased epidermal thickness and increased concentrations of effluents near the mill is strongly supported by other biological effects on perch near the same pulp mill, such as increased prevalences of a gill cover deformity (E. Lindesjöö, J. Thulin, B.-E. Bengtsson \& U. Tjärnlund unpubl.). In addition, a physiological study of perch in the same area also demonstrated that toxic effects were most pronounced in perch from the area closest to the mill (Andersson et al. 1988). Some other effects, including liver enlargement were observed in the whole effluent area. Biochemical tests on livers revealed very strong induction of specific cytochrome P-450-dependent enzyme activity, elevated levels of ascorbic acid and abnomal carbohydrate metabolism, as well as marked effects on leucocyte patterns and alterations in erythrocyte status and ion balance. Other findings for perch in the same area, such as disturbance of population dynamics (Neuman \& Karås 1988), regression of gonad development (Sandström et al. 1988), increased mortality (Sandström \& Thoresson 1988), and increased prevalences of malformed embryos (Karås et al. 1991), were related to the effluent.

Sizes of epithelial cells at all stations in the effluent area corresponded to those previously found in unexposed fish (Lindesjöo 1992). Thus, the difference between cell sizes in fish from the effluent area and from the reference 
Figs. 19 \& 20. Carassius auratus. TEM micrograph of caudal fin of goldfish from a pulp mill effluent area in Kopakorahi Stream, New Zealand. Fig. 19. Acute fin erosion showing hyperemia (white arrows) and edema (black arrows). Note the infiltration of erythrocytes (white arrows) in the epithelium; $\times 1260$. Fig. 20. Enlargement showing lost basement membrane (to right of arrow; $\times 6160$ )
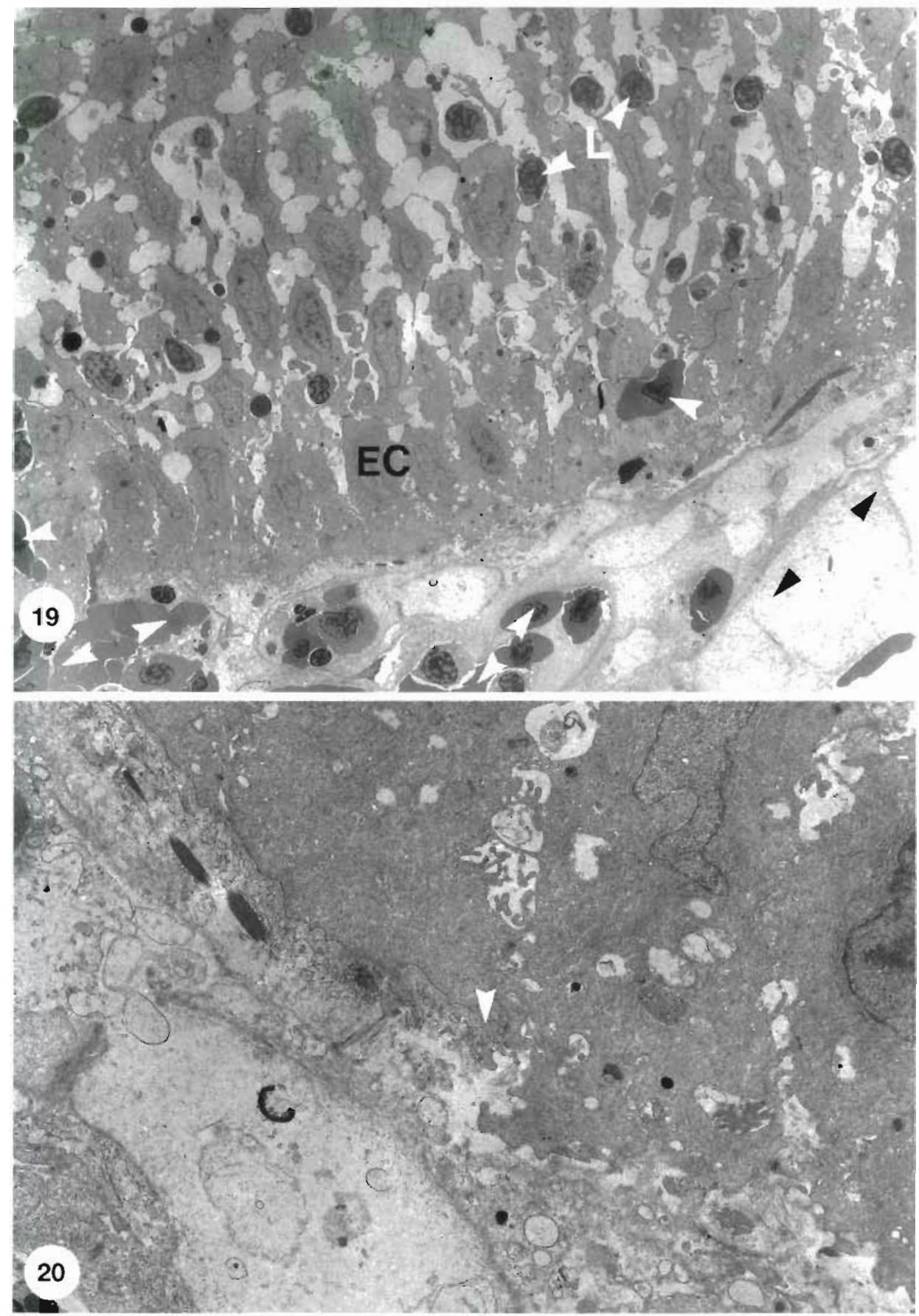

area was not likely to be an effect of effluents from the pulp mill.

In experimental studies made by Karlsson-Norrgren et al. (1986), it was shown that fish exposed to acid water/aluminium exhibited changes of the gills such as an increased diffusion distance, fusion of secondary lamellae, and/or proliferation of chlonde cells. However, morphometry of the secondary gill lamellae in the present study did not show any differences between the different stations, indicatung that the respiratory function of the gills, in terms of morphology, was not affected by effluent at the time of sampling (1985). The same could be suggested for other cellular changes of the gills. Matey (1984) found that gills of perch from an acıdıfied lake were richer in mucus cells. Furthermore, Misra et al. (1987) and Wise et al. (1987) found that fish exposed to nitrofurazone exhibited increased mucus secretion by the gills. However, the present study 
could not demonstrate any difference in mucus secretion between fish from the different stations. Thus, changes found in individuals in 1984 at Stn 2, with pathological deviations of the gills including fusion of secondary lamellae, and fins with healed erosion, indicate that the effluent present at that time might have caused the gill damage.

In conclusion, the study clearly showed that fin erosion of goldfish was identical to the previously described fin erosion of perch: the disease could thus be found in different fish species from different pulp mill effluents. Furthermore, no indications were found of an infectious origin of fin erosion. Instead, the most likely cause was a physiological disturbance of the fish induced by one or more of the toxicants from the pulp mill effluents. Finally, indications were found of hyperplasia of the epidermis which cannot be discounted as being an effect of bleached pulp mill effluents.

Acknowledgements. This work was supported by the Research Council at the Swedish Environmental Protection Agency (SEPA), New Zealand Forest Products, the C. F. Lundströms, C.-F. von Horns and G. and O. Nybelins foundations. Part of the work was performed during a sabbatical stay as a University of Auckland Foundation Visitor (J.T.) at the Department of Zoology, Auckland, New Zealand. We thank G.-B. Ölander, and $\mathrm{H}$. Malmikumpu for assistance with the sectioning work, and Dr. P. Runn for assistance with the gill morphometry. We also thank D. Bucke and Prof. J. E. Kihlström for valuable comments on the manuscript.

\section{LITERATURE CITED}

Andersson, T., Förlin, L., Härdig, J., Larsson, Å. (1988). Physiological disturbances in fish exposed to bleached kraft mill effluents. Can. J. Fish. Aquat. Sci. 45: 1525-1536

Burton, D., Burton, M. P., Idler, D. R. (1984). Epidermal condition in post-spawned winter flounder, Pseudopleuronectes americanus (Walbaum), maintained in the laboratory and after exposure to crude petroleum. J. Fish Biol. 25: 593-606

Cross, J. N. (1984). Fin erosion among fishes collected near a southern Califomia municipal wastewater outfall (1971-1982). Fish. Bull. U.S. 83: 195-206

Daye, P. G., Garside, E. T (1976). Histopathologic changes in surficial tissues of brook trout, Salvelinus fontunalis (Mitchill), exposed to acute and chronic levels of $\mathrm{pH}$. Can. J. Zool. 54: 2140-2155

Dethlefsen, V., Egidius, E., McVicar, A. H. (1984). Methodology of fush disease surveys. Report of the 1984 workshop. Int. Counc. Explor. Sea. Coop. Res. Rep. 140

Haas, H. J. (1962). Studies on mechanisms of joint and bone formation in the skeleton rays of fish fins. Dev. Biol. 5: 1-34

Hibiya, T. (1982). An atlas of fish histology. Normal and pathological features. G. Fischer, Stuttgart

Hinton, D. E., Lanz, R. C., Hampton, J. A., McCuskey, P. R., McCuskey, R. S. (1987). Normal versus abnormal structure: considerations in morphologic responses of teleosts to pollutants. Environ. Hlth Perspectives 71. 139-146

Hughes, G. M., Perry, S. F. (1976). Morphometric study of trout gills: a light-microscopic method suitable for the evaluation of pollutant action. J. exp. Biol. 64: 447-460

Karlsson-Norrgren, L., Björklund, I., Ljungberg, O., Runn, P. (1986). Acid water and aluminium exposure; experimentally induced gill lesions in brown trout Salmo trutta. J. Fish Dis. 9: 11--25

Karås, P., Neuman, E., Sandström, O. (1991). Effects of a pulp mill effluent on the population dynamics of perch, Perca fluviatilis. Can. J. Fish. Aquat. Sci. 48: 28-34

Klontz, G. W., Bendele, R. A. (1973). Histopathological analysis of fin erosion in southern California marine fishes. Rep. TM 203. Southern California Coastal Water Research Project. El Segundo

Kolset, K., Heiberg, A. (1988). Evaluation of the fugacity (FEQUM) and the EXAMS fate and transport models. Case studies on the pollution of the Norrsundet Bay, Sweden. Wat. Sci. Tech. 20: 1-12

Lindesjöö, E. (1992). Fish diseases and pulp mill effluents Epidemiological and histological studies. Acta Univ. Ups. 330

Lindesjöö, E., Thulin, J. (1990). Fin erosion of perch Perca fluviatilis and ruffe Gymnocephalus cernua in a pulp mill effluent area. Dis. aquat. Org. 8: 119-126

Matey, V.E. (1984). Comparative analysis of the gill epithelium ultrastructure in the perch, Perca fluviatilis, from basins with different composition. Tsitologiya 778-782

McDermott-Ehrlich, D. J., Sherwood, M. J., Heesen, T C., Young, D. R., Mearns, A. J. (1977). Chlorinated hydrocarbons in dover sole, Microstomus pacificus: local migrations and fin erosion. Fish. Bull. U.S. 75: 513-517

Mearns, A. J., Sherwood, M. J. (1974). Environmental aspects of fin erosion and tumors in southern California dover sole. Trans. Am. Fish. Soc. 103: 799-810

Misra, V., Chawla, G., Kumar, V., Lal, H., Viswanathan, P. N. (1987). Effect of linear alkyl benzene sulfonate in skin of fish fingerlings, Cirrhina mrigala: observations with scanning electron microscope. Ecotoxicol. Environ. Saf. 13: $164-168$

Murchelano, R. A. (1975). The histopathology of fin rot disease in winter flounder from the New York Bight. J. Wildl. Dis. 11: 263-267

Murchelano, R. A., Ziskowski, J. (1982). Fin rot disease in the New York Bight 1973-1977. In: Mayer, G. F. (ed.) Ecological stress and the New York Bight: science and management. Estuarine Research Federation, Columbia, p. $347-358$

Neuman. E., Karås, P. (1988). Effects of pulp mill effluent on a Baltic coastal fish community. Wat. Sci. Tech. 20: 95-1.06

Pereira, J. J. (1988). Morphological effects of mercury exposure on windowpane flounder gills as observed by scanning electron microscopy. J. Fish Biol. 33: 571-580

Reynolds, E. S. (1963). The use of lead citrate at high pH as an electron-opaque stain in electron microscopy. J. Cell Biol. 17: $208-212$

Sandström, O., Neuman, E., Karås, P. (1988). Effects of a bleached pulp mill effluent on growth and gonad function in Baltic coastal fish. Wat. Sci. Tech. 20: 107-118

Sandström, O., Thoresson, G. (1988). Mortality in perch populations in a Baltic pulp mill effluent area. Mar. Pollut. Bull. 19: 564-567

Sherwood. M. J., Mearns, A. J. (1977). Environmental significance of fin erosion in southern California demersal fishes. Ann. N.Y. Acad. Sci. 298: 177-189

Sindermann, C. J. (1984). Fish and environmental impacts Arch. FischWiss. 35: 125-160

Södergren, A. (ed.) (1989). Biological effects of bleached 
pulp mill effluents. Final report from the Environment/ Cellulose I Project. Report 3558, National Swedish Environmental Protection Board, Solna

Temmink, J. H. M., Bouwmeister, P. J., De Jong, P., Van Den Berg, J. H. J. (1983). An ultrastructural study of chromateinduced hyperplasia in the gill of ranbow trout Salmo gairdneri. Aquat. Toxicol. 4: 165-179

Thulin, J., Höglund, J., Lindesjöö, E. (1988). Diseases and parasites of fish in a bleached kraft mill effluent. Wat. Sci. Tech. 2: 179-180

Wellings, S. R., Alpers, C. E., McCain, B. B., Miller, B. S. (1976). Fin erosion of starry flounder Platichthys stellatus and English sole Parophrys vetulus in the estuary of the Duwamish River, Seattle, Washington. J. Fish. Res. Bd Can. 33: $2577-2586$

Responsible Subject Editor: E. B. Schreck, Corvallis, Oregon, USA
Wingert, R. C., McCain, B. B., Pierce, K. V., Borton, S. F., Griggs, D. T., Miller, B. S. (1976). Ecological and disease studies of demersal fishes in the vicinity of sewage outfalls. In: 1975 Research in Fisheries, Annual Report of the College of Fisheries, University of Washington, Seattle

Wise, M. L., Stiebel, C. L., Grizzle, J. M. (1987). Acute toxicity of nitrofurazone to channel catfish, Ictalurus punctatus, and goldfish. Carassius auratus. Bull. Environ. Contam. Toxicol. 38: 42-46

Ziskowski, J., Murchelano, R. (1975). Fin erosion in winter flounder. Mar. Pollut. Bull. 6: 267-269

Zuchelkowski, E. M., Lantz, C. R., Hinton, D. E. (1986). Skin mucous cell response to acid stress in male and female brown bullhead catfish, Ictalurus nebulosus (Lesueur). Aquat. Toxicol. 8: 139-148

Manuscript first received: May 17, 1993

Revised version accepted: October 11, 1993 